\title{
ОКСИДАТИВНІ МЕХАНІЗМИ РОЗВИТКУ АДРЕНАЛІНОВОГО ПОШКОДЖЕННЯ МІОКАРДА У ЩУРІВ РІЗНОЇ СТАТІ
}

Вступ. При часто повторюваних або сильних стресах в організмі зростає концентрація катехоламінів, що спричинює розвиток серцево-судинної патології.

Мета дослідження - оцінити розвиток оксидативного стресу в гомогенаті серця самців і самиць щурів при адреналіновому пошкодженні міокарда.

Методи дослідження. Досліди виконано на безпородних щурах масою 180-220 г. Адреналінове пошкодження міокарда викликали адреналіном (0,5 мг/кг), забір серця проводили через 1 та 24 год після ін'єкції, визначали вміст дієнових кон'югатів, ТБК-активних продуктів, окисномодисрікованих протеїнів, супероксиддисмутазну і каталазну активність. Усім тваринам проводили морфологічне дослідження серця на рівні обох шлуночків, під час якого було підтверджено виникнення некрозів у мікропрепаратах, зафрарбованих за Гейденгайном. Кількість некрозів переважала у самців у 2 терміни дослідження і значно підвищувалася через 24 год порівняно з 1 год, що знову ж таки більш виражено серед самців.

Результати й обговорення. У самців контрольної групи переважали продукти пероксидного окиснення ліпідів і окисномодифріковані протеїни, а в самиць переважала активність антиоксидантів. На початку розвитку адреналінового пошкодження міокарда у самців та самиць збільшилися вміст дієнових кон'югатів, ТБК-активних продуктів, супероксиддисмутазна і каталазна активність, а підвищення вмісту окисномодифрікованих протеїнів відмічено тільки серед самців. Зміни показників, що вказували на розвиток оксидативного стресу, були достовірно більшими у самців. Через 24 год після введення адреналіну відзначено подальше зростання вмісту дієнових кон'югатів, ТБК-активних продуктів, окисномодифрікованих протеїнів порівняно з контролем і попереднім терміном дослідження. Також спостерігали зниження антиоксидантної активності, але тільки у самців. Зміни показників, що свідчили про розвиток пошкодження, були достовірно більшими у самців.

Висновки. Розвиток адреналінового пошкодження серця залежить від статі. Більш виражену різницю відмічено протягом усього експерименту. Вища вихідна активність антиоксидантної системи запобігає значному пошкодженню міокарда в самиць.

КЛЮЧОВІ СЛОВА: пероксидне окиснення ліпідів; антиоксидантна система; серце; адреналін.

ВСТУП. У захворюваності серцево-судинної системи провідне місце займає проблема некротичних пошкоджень міокарда. Однією з причин виникнення некрозу може бути вплив стресу (надмірної сили, великої частоти, з різними періодами повторюваності між стресовими епізодами) з виділенням великої концентрації катехоламінів. При цьому в клітинах запускається каскад реакцій, що спричинюють розвиток гіпоксії $[1,2]:$ зменшується напруження оксигену в крові й тканинах $\rightarrow$ знижується концентрація АТФ $\rightarrow$ накопичуються іони кальцію $\rightarrow$ підвищується активність фоосфорилаз $\rightarrow$ виникає електрична дестабілізація мембран $\rightarrow$ збільшується проникність мембран для іонів $\rightarrow$ відбувається роз'єднання процесів окиснення і фросорорилювання $\rightarrow$ настає загибель клітин на фроні зростання енер() О. В. Денефіль, Т. Я. Ярошенко, Ю. А. Свередюк, С. М. Чарнош, 2021. годефріциту. При гіпоксії, впливі катехоламінів в організмі зростає швидкість вільнорадикальних реакцій, що залежить від рівня метаболізму, ступеня активації системи антиоксидантного захисту, зокрема антирадикальних ензимів (глутатіонпероксидаза, супероксиддисмутаза, каталаза) та природних антиоксидантів (токоферол, аскорбінова кислота), які зменшують швидкість окисних процесів [2-4].

Виникнення, перебіг і наслідки захворювання значно залежать від реактивності організму [5], статі, що забезпечує генетично різну резистентність до стресів, холоду, крововтрат, гіпоксії [6].

Мета дослідження - оцінити розвиток оксидативного стресу в гомогенаті серця самців і самиць щурів при адреналіновому пошкодженні міокарда. 
МЕТОДИ ДОСЛІДЖЕННЯ. Досліди виконано на безпородних щурах масою 180-220 г. Тварин було поділено на 2 групи: контроль, адреналінове пошкодження міокарда (АПМ).

Групи тварин утримували на стандартному харчовому раціоні віварію протягом усього періоду та з вільним доступом до води для пиття. Для моделювання АПМ щурам внутрішньом'язово вводили 0,18 \% розчин адреналіну гідротартрату з розрахунку 0,5 мг/кг маси. Дослідження проводили через 1 і 24 год після ін'єкції препарату, що відповідає початку розвитку міокардіодистросрії та розгорнутій картині патологічного процесу. Всім тваринам проводили гістологічне дослідження серця на рівні обох шлуночків, під час якого було підтверджено виникнення некрозів у мікропрепаратах, засрарбованих за Гейденгайном. Кількість некрозів переважала у самців у 2 терміни дослідження і значно підвищувалася через 24 год порівняно з 1 год, що знову ж таки більш виражено серед самців.

Усі експерименти проводили в першій половині дня в спеціально відведеному приміщенні при температурі $18-22{ }^{\circ} \mathrm{C}$, відносній вологості 40-60 \% і освітленості 250 лк. Досліди виконано з дотриманням норм Європейської конвенції про захист хребетних тварин, що використовуються для дослідних та інших наукових цілей (Страсбург, 18.03.1986 р.), ухвали Першого національного конгресу з біоетики (Київ, 2001) і наказу МОЗ України від 23.09.2009 р. № 690.

Евтаназію щурів проводили шляхом тотального кровопускання із серця після попереднього використання тіопентал-натрієвого наркозу (60 мг $\cdot \mathrm{k}^{-1}$ маси тіла тварини внутрішньочеревно). 3 використанням загальноприйнятих методику гомогенаті серця визначали стан пероксидного окиснення ліпідів (ПОЛ) за вмістом дієнових кон'югатів (ДК), ТБК-активних продуктів (ТБК-ап), окисну модифікацію протеїнів $\left(\mathrm{OM} \Pi_{370}\right.$ i ОМП та активність антиоксидантної системи, зокрема супероксиддисмутазну і каталазну активність [7-10].

Статистичну обробку цифррових даних виконано за допомогою програмного забезпечення
Excel ("Microsoft", CШA) i STATISTICA 6.0 ("Statsoft", США). Достовірність різниці значень між незалежними кількісними величинами визначали при нормальному розподілі за критерієм Стьюдента, в інших випадках - за допомогою непараметричних методів. Зміни вважали достовірними при $\mathrm{p} \leq 0,05$. Відмінності між величинами вважали достовірними за вірогідності альтернативної гіпотези не менше ніж 0,95 [11].

РЕЗУЛЬТАТИ Й ОБГОВОРЕННЯ. ПрОТЯГОМ перших 15 хв від початку експерименту відмічено смертність щурів: серед самців вона становила 9,3\%, серед самиць - 3,2\%.

Серед контрольних самців і самиць щурів вміст продуктів ПОЛ був вищим у самців (табл. 1). Так, концентрація ДК збільшилась на 17,9 \%, а ТБК-ап - на 9,1 \%. Відповідно, вищими були показники ОМП відповідно (табл. 2). Супероксиддисмутазна і каталазна активність переважала в самиць - на 17,3 та 18,3 \% відповідно (табл. 3). Отримані дані вказують на те, що вища активність антиоксидантів попереджує активацію ПОЛ у самиць.

Уведення розчину адреналіну призвело до таких змін. Через 1 год відмічено достовірне збільшення практично всіх досліджуваних показників у самців і практично всіх у самиць. Так, концентрація ДК у самців зросла на 12,1 \%, у самиць - на 16,7 \% і була вищою у самців на $13,3 \%$. Вміст ТБК-ап у самців збільшився у 2,7 раза, в самиць - на 52,3 \% і був вищим у самців на 95,5\%. Значення ОМП ся тільки у самців - на $39 \%$, а в самиць зміни були недостовірними, показники ОМП ${ }_{430}$ У самців зросли на 32,4 \%, у самиць зміни знову були недостовірними. Значення ОМП переважали у самців - на 76,3 і 49,2 \% відповідно. Супероксиддисмутазна активність у самців підвищилася на $16,3 \%$, у самиць - на 59,1 \% і була більшою в самиць на $60,5 \%$. Каталазна активність у самців зросла на 17,6 \%, у самиць - на 68,4 \% і переважала в самиць на 69,5 \%. Отримані дані вказують на те, що більша вихідна потужність антиоксидантної системи забезпечує постійне

Таблиця 1 - Зміни вмісту продуктів пероксидного окиснення ліпідів у гомогенаті серця щурів при адреналіновому пошкодженні міокарда (M士m)

\begin{tabular}{|c|c|c|c|c|c|c|}
\hline \multirow{4}{*}{ Показник } & \multicolumn{6}{|c|}{ Група } \\
\hline & \multirow{2}{*}{\multicolumn{2}{|c|}{ контроль }} & \multicolumn{4}{|c|}{ АПМ } \\
\hline & & & \multicolumn{2}{|c|}{1 год } & \multicolumn{2}{|c|}{24 год } \\
\hline & самці $(\mathrm{n}=8)$ & самиці $(\mathrm{n}=7)$ & самці $(n=9)$ & самиці $(\mathrm{n}=8)$ & самці (n=7) & самиці $(\mathrm{n}=8)$ \\
\hline ДК, ум. од./г & $0,99 \pm 0,02$ & $0,84 \pm 0,02^{\star \star}$ & $1,11 \pm 0,03^{*}$ & $0,98 \pm 0,02^{\star, \star \star}$ & $2,21 \pm 0,04^{\star, \star \star \star}$ & $1,02 \pm 0,02^{*}$ \\
\hline $\begin{array}{l}\text { ТБК-аП, } \\
\text { мкмоль/кг }\end{array}$ & $0,96 \pm 0,02$ & $0,88 \pm 0,02^{\star}$ & $2,62 \pm 0,05^{*}$ & $1,34 \pm 0,03^{*, * *}$ & $5,65 \pm 0,06^{\star, \star \star \star}$ & $2,92 \pm 0,04^{\star, \star \star, \star \star \star \star}$ \\
\hline
\end{tabular}

Примітка. Тут і в таблицях 2, 3: * - різниця достовірна порівняно з контролем; ** - різниця достовірна порівняно із самцями; *** - різниця достовірна порівняно з 1 год розвитку АПМ. 
Таблиця 2 - Зміни вмісту окисномодифікованих протеїнів у гомогенаті серця щурів при адреналіновому пошкодженні міокарда (Mm)

\begin{tabular}{|c|c|c|c|c|c|c|}
\hline \multirow{4}{*}{ Показник } & \multicolumn{6}{|c|}{ Гррупа } \\
\hline & \multirow{2}{*}{\multicolumn{2}{|c|}{ контроль }} & \multicolumn{4}{|c|}{ АПM } \\
\hline & & & \multicolumn{2}{|c|}{1 год } & \multicolumn{2}{|c|}{24 год } \\
\hline & самці $(\mathrm{n}=8)$ & самиці $(\mathrm{n}=7)$ & самці $(n=9)$ & самиці $(\mathrm{n}=8)$ & самці $(n=7)$ & самиці (n=8) \\
\hline ОМП $_{370}$, ммоль/г протеїну & $1,18 \pm 0,01$ & $0,89 \pm 0,03^{\star \star}$ & $1,64 \pm 0,04^{*}$ & $0,93 \pm 0,02^{\star \star}$ & $1,98 \pm 0,01^{\star, \star \star \star}$ & $1,17 \pm 0,02^{\star, \star \star, \star \star \star}$ \\
\hline $\mathrm{OMП}_{430}$, ммоль/г протеїну & $0,71 \pm 0,01$ & $0,58 \pm 0,02^{\star \star}$ & $0,94 \pm 0,06^{*}$ & $0,63 \pm 0,03^{\star \star}$ & $1,24 \pm 0,05^{\star, \star \star \star}$ & $0,82 \pm 0,02^{\star, \star \star, \star \star \star}$ \\
\hline
\end{tabular}

Таблиця 3 - Зміни активності антиоксидантів у гомогенаті серця щурів при адреналіновому пошкодженні міокарда (M士m)

\begin{tabular}{|c|c|c|c|c|c|c|}
\hline \multirow{4}{*}{ Показник } & \multicolumn{6}{|c|}{ Група } \\
\hline & \multirow{2}{*}{\multicolumn{2}{|c|}{ контроль }} & \multicolumn{4}{|c|}{ АПМ } \\
\hline & & & \multicolumn{2}{|c|}{1 год } & \multicolumn{2}{|c|}{24 год } \\
\hline & самці $(n=8)$ & самиці n=7) & самці $(n=9)$ & самиці $(\mathrm{n}=8)$ & самці (n=7) & самиці (n=8) \\
\hline $\begin{array}{l}\text { Супероксиддисмутазна } \\
\text { активність, ум. од./мг }\end{array}$ & $0,98 \pm 0,02$ & $1,15 \pm 0,03^{\star \star}$ & $1,14 \pm 0,06^{*}$ & $1,83 \pm 0,06^{\star, \star \star}$ & $0,62 \pm 0,04^{*, \star \star \star}$ & $1,62 \pm 0,02^{\star, \star \star, \star \star \star \star}$ \\
\hline $\begin{array}{l}\text { Каталазна активність, } \\
\text { мкат/кг }\end{array}$ & $1,31 \pm 0,06$ & $1,55 \pm 0,03^{\star \star}$ & $1,54 \pm 0,06^{\star}$ & $2,61 \pm 0,08^{\star, \star \star}$ & $1,21 \pm 0,04^{\star \star \star}$ & $1,98 \pm 0,03^{\star, \star \star, \star \star \star \star}$ \\
\hline
\end{tabular}

знешкодження вільних радикалів, а на початку розвитку АПМ, поряд із посиленням процесів руйнування клітинних мембран, відмічено підвищення активності антиоксидантів, щоправда в значно меншому відсотковому показнику порівняно з продуктами ПОЛ і ОМП, вміст яких зростає.

Через 24 год АПМ, порівняно з контролем, концентрація ДК у самців зросла у 2,2 раза, в самиць - на 21,4 \% і була вищою у самців у 2,2 раза. Вміст ТБК-ап у самців збільшився у 5,9 раза, в самиць - у 3,3 раза і був вищим у самців у 2 рази. Значення ОМП 370 у самців підвищилися на 67,8 \%, у самиць - на 31,5\%, показники ОМП 430 у самців зросли на 74,6 \%, у самиць - на 41,4 \%. Значення ОМП переважали у самців - на 69,2 і 51,2 \% відповідно. Супероксиддисмутазна активність у самців знизилася на 36,7 \%, у самиць вона підвищилася на 40,9 \% і була більшою в самиць у 2,6 раза. Каталазна активність у самців не змінилася, а в самиць вона зросла на 27,7 \% і була вищою в самиць на 63,6 \%. Отримані дані вказують на те, що більша вихідна потужність антиоксидантної системи забезпечує постійне знешкодження вільних радикалів, а на початку розвитку адреналінової кардіоміопатії, коли процес тільки починається, поряд із наростанням процесів руйнування клітинних мембран, відмічено зростання активності антиоксидантів, щоправда в значно меншому відсотковому показнику, порівняно з продуктами ПОЛ і ОМП.
При порівнянні досліджуваних показників через 1 і 24 год після введення адреналіну відмічено поглиблення розвитку патологічного процесу, більш виражено у самців. Так, вміст ДК через 24 год збільшився тільки у самців - на $9 \%$. Концентрація ТБК-ап у самців була вищою у 2,6 раза, в самиць -у 2,2 раза. Значення ОМП у самців переважали на 18,3 \%, у самиць - на $25,8 \%$, показники ОМП 430 у самців були більшими на 31,9 \%, у самиць - на 30,2 \%. Супероксиддисмутазна активність у самців була нижчою на $45,6 \%$, у самиць - на 25,8 \%. Каталазна активність у самців зменшилась на 21,4 \%, у самиць на 24,1 \%. Отримані дані вказують на те, що більша вихідна потужність антиоксидантної системи забезпечує постійне знешкодження вільних радикалів, але при поглибленні патологічного процесу знижується вміст антиоксидантів, що призводить до наростання продуктів ПОЛ і ОМП.

Одержані дані щодо змін біохімічних показників узгоджуються $з$ морфологічними змінами, які вказують на більше пошкодження кардіоміоцитів у самців.

ВИСНОВКИ. Розвиток адреналінового пошкодження серця залежить від статі. Більш виражену різницю відмічали протягом усього експерименту. Вища вихідна активність антиоксидантної системи запобігає значному пошкодженню міокарда в самиць. 


\section{СПИСОК ЛІТЕРАТУРИ}

1. Corcoran A. Hypoxia-inducible factor signaling mechanisms in the central nervous system / A. Corcoran, J. J. O'Connor // Acta Physiol. (Oxf). - 2013. - 208, No. 4. - P. 298-310.

2. Механизмы фрормирования острой экзогенной гипоксии и возможности ее фрармакологической коррекции антигипоксантами / Д. В. Сосин, О. Е. Шалаева, А. В. Евсеев, П. Д. Шабанов // Обзоры по клинической фармакологии и лекарственной терапии. 2015. - 13, № 1. - C. 1-24.

3. Antioxidant and cytoprotective responses to redox stress / J. Mathers, J. A. Fraser, M. McMahon [et al.] // Biochem. Soc. Symp. - 2004. - No. 71. - P. 157-176.

4. Colombo M. L. An update on vitamin E, tocopherol and tocotrienol -perspectives / M. L. Colombo // Molecules. - 2010. - 15, No. 4. - P. 2103-2113.

5. A possible role for systemic hypoxia in the reactive component of pulmonary hypertension in heart failure / B. J. Taylor, C. R. Mojica, T. P. Olson [et al.] // Journal of Cardiac Failure. - 2013. - 19, Issue 1. - P. 50-59.

6. Устойчивость к гипоксии у людей пожилого возраста с гипертонической болезнью: влияние Кар-

\section{REFERENCES}

1. Corcoran, A. \& O'Connor, J.J. (2013). Hypoxiainducible factor signaling mechanisms in the central nervous system. Acta Physiol. (Oxf), 208 (4), 298-310.

2. Sosin, D.V., Shalaeva, O.E., Evseev, A.V., \& Shabanov, P.D. (2015). Mekhanismy formirovaniya ostroy ekzogennoy gipoksii i vosmozhnosti ego farmakologicheskoy korrektsii antihipoksantami [Mechanisms of the formation of acute exogenous hypoxia and the possibility of its pharmacological correction with antihypoxants]. Obzory po klinicheskoy farmakologii i lekarstvennoy terapii - Reviews on Clinical Pharmacology and Drug Therapy, 13 (1), 1-24 [in Russian].

3. Mathers, J., Fraser, J.A., McMahon, M., Saunders, R.D., Hayes, J.D. \& McLellan, L.I. (2004). Antioxidant and cytoprotective responses to redox stress. Biochem. Soc. Symp., 71, 157-176.

4. Colombo, M.L. (2010). An update on vitamin E, tocopherol and tocotrienol -perspectives. Molecules, 15 (4), 2103-2113.

5. Taylor, B.J., Mojica, C.R., Olson, T.P., Woods, P.R., Frantz, R.P. \& Johnson, B.D, (2013). A possible role for systemic hypoxia in the reactive component of pulmonary hypertension in heart failure. Journal of Cardiac Failure, 19 (1), 50-59.

6. Korkushko, O.V., Osmak, E.D., Ocmak, D.D., \& Duzhak, G.V. (2015). Ustoychivost k gipoksii u lyudey pozhilogo vozrzsta s gipertonicheskoy boleznyu: vliyanie Cardioarginina [Resistance to hypoxia in elderly people with essential hypertension: the effect of Cardioarginin]. Krovoobih i hemostas - Blood Circulation and Hemostasis, 1-2, 31-37 [in Russian]. диоаргинина / О. В. Коркушко, Е. Д. Осьмак, Д. Д. Осьмак, Г. В. Дужак // Кровообіг та гемостаз. - 2015. № 1-2. - С. 31-37.

7. Хышиктуев Б. С. Методы определения продуктов перекисного окисления липидов в конденсате выдыхаемого воздуха и их клиническое значение / Б. С. Хышиктуев, Н. А. Хышиктуева, В. Н. Иванов // Клинич. лаб. диагностика. - 1996. - № 3. - С. 13-15.

8. Мещишен І. Ф. Метод визначення окислювальної модифрікації білків плазми крові / І. Ф. Мещишен // Буковин. мед. вісн. - 1998. - 2, № 1. - С. 156-158.

9. Чевари С. Роль супероксиддисмутазы в окислительных процессах клетки и метод определения ее в биологических материалах / С. Чевари, И. Чаба, Й. Секей // Лаб. дело. - 1985. - № 11. - С. 678-681.

10. Метод определения активности каталазы / М. А. Королюк, Л. И. Иванова, И. Г. Майорова, В. Е. Токарев // Лаб. дело. - 1988. - № 1. - С. 16-19.

11. Лапач С. Н. Статистические методы в медико-биологических исследованиях с использованием Excel / С. Н. Лапач, А. В. Чубенко, П. Н. Бабич. - К. : Морион, 2000. - 320 с.
7. Khyshiktyev, B.S., Khyshiktyeva, N.A. \& Ivanov V.N. (1996). Metody opredeleniya produktov perekisnogo okisleniya lipidov v kondensate vydykhaemogo vozdukha i ikh klinicheskoe znachenie [Methods for determination of lipid peroxidation products in exhaled air condensate and their clinical significance]. Klinicheskaya laboratornaya diagnostica - Clinical Laboratory Diagnostic, 3, 13-15 [in Russian].

8. Meshchyshen, I.F. (1998). Metod vyznachennia okuslyuvalnoi modyfikatsii bilkiv plazmy krovi [Method for determination of oxidative modification of blood plasma proteins]. Bukovynskyi medychnyi visnyk - Bukovynian Medical Bulletin, 2 (1), 156-158 [in Ukrainian].

9. Chevari, S., Chaba, I. \& Sekei, I. (1985). Rol superoksiddismutazy $v$ okislitelnykh protsessakh kletki i metod opredeleniya ego $v$ biologicheskikh materialakh [The role of superoxide dismutase in the oxidative processes of the cell and the method for its determination in biological materials]. Lab. delo - Laboratoty Business, 11, 678-681 [in Russian].

10. Korolyuk, M.A., Ivanova, L.I., Mayorova, I.G., \& Tokarev, V.E. (1988). Metod opredeleniya aktivnosti katalazy [Method for determination of catalase activity]. Lab. delo - Laboratory Business, 1, 16-19 [in Russian].

11. Lapach, S.N., Chubenko, A.V., \& Babich, P.N. (2000). Statisticheskie metody v mediko-biologicheskikh issledovaniyakh s ispolzovaniem Excel [Statistical methods in biomedical research using Excel]. Kyiv: Morion [in Russian]. 


\section{OXIDATIVE MECHANISMS OF ADRENALINE MYOCARDIAL DAMAGE DEVELOPMENT IN RATS OF DIFFERENT SEX}

\section{Summary}

Introduction. In frequent or severe stress, the concentration of catecholamines in the body increases, which causes the development of cardiovascular pathology.

The aim of the study - to evaluate the development of oxidative stress in the heart homogenate of male and female rats with adrenaline myocardial damage (AMD).

Research Methods. The experiments were performed on outbred rats weighing 180-220 grams. AMD was induced by adrenaline $(0.5 \mathrm{mg} / \mathrm{kg})$, heart sampling was performed 1 and 24 hours after injection, where diene conjugates (DC), TBA-active products, oxidative modified proteins, superoxide dismutase (SOD) and catalase activity were determined. All animals underwent morphological investigation of the heart at the ventricles levels, which confirmed the occurrence of necrosis in micronutrients stained by Geidengain. The level of necrosis prevailed in males rats in AMD of two studies, and also increased during 24 hours, compared with 1 hour, which was also higher than in females.

Results and Discussion. Lipid peroxidation (LPO) and oxidative modified proteins products predominated in males, and antioxidant activity prevailed in females in control. At the beginning of the development of AMD males and females increased DC, TBA-active products, SOD, catalase activity, and an increase in oxidative modified proteins was observed only among males. Changes in indicators indicating the development of oxidative stress were significantly higher in males. In 24 hours after injection of adrenaline the further increase of DC, TBA-active products, oxidative modified proteins, in comparison with control and the previous term of research is noted. There was also a decrease in antioxidant activity, but only in males. Changes in the indicators indicating the development of damage were significantly greater in males.

Conclusions. The development of adrenaline damage to the heart depends on sex. A more pronounced difference was observed throughout the experiment. Greater initial activity of the antioxidant system prevents significant myocardial damage in females.

KEY WORDS: lipid peroxidation; antioxidant system; heart; adrenaline.

Отримано 30.08.21

Адреса для листування: О. В. Денефріль, Тернопільський національний медичний університет імені І. Я. Горбачевського мОз Украӥни, майдан Волі, 1, Тернопіль, 46001, Україна, e-mail: denefil@tdmu.edu.uа. 